\title{
Message From the Editor-in-Chief
}

Dear Colleagues

On behalf of the Circulation Journal, I would like to let you know the top 30 most frequently cited papers among the previous 16,486 Japanese Circulation Journal (1968-2001)/Circulation Journal (2002-2009 July) papers (numbers in parentheses denote the number of citations).

(1) (284) The Examination Committee of Criteria for 'Obesity Disease' in Japan, Japan Society for the Study of Obesity. New criteria for 'obesity disease' in Japan. Circ J 2002; 66: 987-992 (Review).

(2) (246) Kitabatake A, Inoue M, Asao M, Tanouchi J, Masuyama T, Abe H, et al. Transmitral blood flow reflecting diastolic behavior of the left ventricle in health and disease: A study by pulsed Doppler technique. Jpn Circ J 1982; 46: 92-102.

(3) (151) Ryo M, Nakamura T, Kihara S, Kumada M, Shibazaki S, Takahashi M, et al. Adiponectin as a biomarker of the metabolic syndrome. Circ J 2004; 68: 975-981.

(4) (147) Hamano K, Nishida M, Hirata K, Mikamo A, Li TS, Harada M, et al. Local implantation of autologous bone marrow cells for therapeutic angiogenesis in patients with ischemic heart disease: Clinical trial and preliminary results. Jpn Circ J 2001; 65: 845-847.

(5) (135) Aoki K, Yamori Y, Ooshima A, Okamoto K. Effects of high or low sodium intake in spontaneously hypertensive rats. Jpn Circ J 1972; 36: 539-545.

(6) (121) Kawai S, Suzuki H, Yamaguchi H, Tanaka K, Sawada H, Aizawa T, et al. Ampulla cardiomyopathy ('Takotusbo' cardiomyopathy): Reversible left ventricular dysfunction with ST segment elevation. Jpn Circ J 2000; 64: 156-159.

(7) (115) Kawai C. Idiopathic cardiomyopathy: A study on infectious-immune theory as a cause of the disease. Jpn Circ J 1971; 35: 765-770.

(8) (113) Yamori Y, Nagaoka A, Okamoto K. Importance of genetic factors in stroke: An evidence obtained by selective breeding of stroke-prone and -resistant SHR. Jpn Circ J 1974; 38: 1095-1100 (Review).

(9) (107) Yamori Y. Pathogenesis of spontaneous hypertension as a model for essential hypertension. Jpn Circ J 1977; 41: 259-266 (Review).

(10) (97) Ueyama T, Kasamatsu K, Hano T, Yamamoto K, Tsuruo Y, Nishio I. Emotional stress induces transient left ventricular hypocontraction in the rat via activation of cardiac adrenoceptors: A possible animal model of 'tako-tsubo' cardiomyopathy. Circ J 2002; 66: 712-713.

(10) (97) Tanase H, Suzuki Y, Ooshima A, Yamori Y, Okamoto K. Genetic analysis of blood pressure in spontaneously hypertensive rats. Jpn Circ J 1970; 34: 1197-1212.

(12) (81) Sekiguchi M, Numao Y, Imai M, Furuie T, Mikami R. Clinical and histopathological profile of sarcoidosis of the heart and acute idiopathic myocarditis: Concepts through a study employing endomyocardial biopsy: I. Sarcoidosis. Jpn Circ J 1980; 44: 249-263.

(13) (78) Yamaguchi T, Minematsu K, Choki J, Ikeda M. Clinical and neuroradiological analysis of thrombotic and embolic cerebral infarction. Jpn Circ J 1984; 48: 50-58.

(13) (78) Yasue H, Omote S, Takizawa A, Nagao M, Miwa K, Kato H, et al. Pathogenesis and treatment of angina pectoris at rest as seen from its response to various drugs. Jpn Circ J 1978; 42: 1-10.

(13) (78) Kawamura K, Kashii C, Imamura K. Ultrastructural changes in hypertrophied myocardium of spontaneously hypertensive rats. Jpn Circ J 1976; 40: 1119-1145.

(16) (77) Yamori Y, Matsumoto M, Yamabe H, Okamoto K. Augmentation of spontaneous hypertension by chronic stress in rats. Jpn Circ J 1969; 33: 399-409.

(17) (76) Komachi Y, Iida M, Shimamoto T, Chikayama Y, Takahashi H, Konishi M, et al. Geographic and occupational comparisons of risk factors in cardiovascular diseases in Japan. Jpn Circ J 1971; 35: 189-207.

(18) (74) Amano S, Hazama F, Hamashima Y. Pathology of Kawasaki disease: I. Pathology and morphogenesis of the vascular changes. Jpn Circ J 1979; 43: 633-643. 
(19) (71) Ehara M, Surmely JF, Kawai M, Katoh O, Matsubara T, Terashima M, et al. Diagnostic accuracy of 64-slice computed tomography for detecting angiographically significant coronary artery stenosis in an unselected consecutive patient population: Comparison with conventional invasive angiography. Circ J 2006; 70: 564-571.

(19) (71) Ichijima K. Morphological studies on peripheral small arteries of spontaneously hypertensive rats. Jpn Circ J 1969; 33: 785-813.

(21) (70) Hori M, Yeliin EL, Sonnenblick EH. Left ventricular diastolic suction as a mechanism of ventricular filling. Jpn Circ J 1982; 46: 124-129 (Review).

(22) (69) Matsuzaki M, Kita T, Mabuchi H, Matsuzawa Y, Nakaya N, Oikawa S, et al. Large scale cohort study of the relationship between serum cholesterol concentration and coronary events with lowdose simvastatin therapy in Japanese patients with Hypercholesterolemia: Primary prevention cohort study of the Japan Lipid Intervention Trial (J-LIT). Circ J 2002; 66: 1087-1095.

(23) (68) Owa M, Aizawa K, Urasawa N, Ichinose H, Yamamoto K, Karasawa K, et al. Emotional stressinduced 'ampulla cardiomyopathy': Discrepancy between the metabolic and sympathetic innervation imaging performed during the recovery course. Jpn Circ J 2001; 65: 349-352.

(24) (64) Fontaine G, Frank R, Tonet JL, Guiraudon G, Cabrol C, Chomette G, et al. Arrhythmogenic right ventricular dysplasia: A clinical model for the study of chronic ventricular tachycardia. Jpn Circ J 1984; 48: 515-538 (Review).

(25) (63) Kodama K, Sasaki H, Shimizu Y. Trend of coronary heart disease and its relationship to risk factors in a Japanese population: A 26-year follow-up, Hiroshima/Nagasaki study. Jpn Circ J 1990; 54: 414-421.

(26) (62) Suga H, Hisano R, Goto Y, Yamada O. Normalization of end-systolic pressure-volume relation and Emax of different sized hearts. Jpn Circ J 1984; 48: 136-143.

(26) (62) Suzuki Y, Kamikawa T, Kobayashi A, Masumura Y, Yamazaki N. Effects of L-carnitine on tissue levels of acyl carnitine, acyl coenzyme A and high energy phosphate in ischemic dog hearts. Jpn Circ J 1981; 45: 687-694.

(28) (61) Noda S. Histopathology of endomyocardial biopsies from patients with idiopathic cardiomyopathy: Quantitative evaluation based on multivariate statistical analysis. Jpn Circ J 1980; 44: 95-116 (Review).

(28) (61) Aoki K, Ikeda N, Yamashita K, Tazumi K, Sato I, Hotta K. Cardiovascular contraction in spontaneously hypertensive rat: $\mathrm{Ca}^{2+}$ interaction of myofibrils and subcellular membrane of heart and arterial smooth muscle. Jpn Circ J 1974; 38: 1115-1121.

(30) (59) Shimokawa H. Cellular and molecular mechanisms of coronary artery spasm: Lessons from animal models. Jpn Circ J 2000; 64: 1-12 (Review).

The Editorial Team looks forward to receiving manuscripts with high scientific impact from all over the world.

Hiroaki Shimokawa, MD, PhD

Editor-in-Chief

Circulation Journal 